\title{
Exploring Teachers' Pedagogical Practices in Teaching Mandarin as a Foreign Language in MARA Educational Institutions, Malaysia
}

\author{
Nuraini Jafri, Umi Kalthom Abd Manaf and Fazilah Razali \\ Universiti Putra Malaysia, Malaysia \\ http://orcid.org/0000-0003-3833-1895 \\ http://orcid.org/0000-0002-4793-8165 \\ http://orcid.org/0000-0002-1203-1010
}

\begin{abstract}
In recent years, it has become evident that pedagogical practices used by teachers significantly contribute to ensuring the quality of students' learning. However, the existing literature on teachers' pedagogical practice reveals that there are very few qualitative explanatory studies on teaching Mandarin as a foreign language, specifically in Malaysia. Hence, this research aimed to explore teachers' pedagogical practices in teaching Mandarin as FL, including their perceptions of the research. This qualitative case study collected data through six semi-structured interviews with Mandarin teachers working under MARA colleges. These informants were chosen by using a convenience purposive sampling method. The data analyzed using Atlas. ti revealed that teachers are still using a traditional teaching style, as well as the pre-established beliefs that the teachers had in knowledge constructions and 21st-century skills. Beyond that, the findings also indicated the Mandarin teachers need professional development opportunities as the majority of them described the signs of job burnout. After careful data analysis, the researcher proposed this research to be further explored from the perspectives of language learners. Besides that, it is recommended to explore the inculcation of $21^{\text {st }}$-century pedagogy, including grounding the theory of Mandarin teachers' pedagogical practices.
\end{abstract}

Keywords: language teacher; pedagogical practices; Mandarin language; foreign language

\section{Introduction}

"It matters not what someone is born, but what they grow to be!". This is Albus Dumbledore was berating Cornelius Fudge, the Minister of Magic for blindly ignoring one's fault because of one's family background. This particular scene from Harry Potter and the Goblet of Fire book (2002) highlighted the nature of a teacher through the role of Professor Albus Dumbledore for treating the students 
equally, without choosing any favorites. A real teacher does not look out for who a person's parent is, where, or what their lineage looks like, or how much natural talent they may possess. Instead, the teacher will focus more on growing and developing the existing talent that one has because mighty oaks from little acorns grow. Furthermore, there is a countless number of amazing teacher stories that portrayed the importance of a strong teacher-student relationship (Marzano, 2003; Baker, 2006; Hallinan, 2008). It is the teacher that makes the difference in a student's life and not the classroom. The beliefs and practices that the teachers uphold are vital in understanding and improving the educational processes (Ciliers, 2017). These beliefs are very important in teaching the new Generation Generation Z, a generation that surpasses the classical, conventional teachinglearning approaches. Teaching the new millennial generation require teachers to explore various ways to apprehend the understanding, interest, and imagination of this "connected" Generation Z.

Teachers' responsibilities are beyond academic achievement. By forging a strong relationship, teachers are the most influential persons for developing students' potentials. It is closely related to the methodologies on how teachers dealt from their general well-being to professional daily life, to the extent of shaping students' learning environment, as well as influencing the students' motivation and achievement. The teachers can virtually affect their students' lives in every aspect, particularly teaching them the essential life experience which will help and prepare them to successfully thrive beyond test papers and standardized examinations. According to the United Nations Educational, Scientific, and Cultural Organization (UNESCO), producing a lifelong learner is the ultimate goal of education in the $21^{\text {st }}$ century (Collins, 2009). All of the scenarios described above are the act of teachers in cultivating and ensuring a lifelong learning environment among the students.

\section{Problem Statement}

Teachers' pedagogical practices are crucial, especially in addressing the quality of students' learning. The beliefs that instilled within the teachers are a very compelling force, especially in making the decision and taking actions that also may influence the student's achievement (Fullan, 2001; 2003). These beliefs may be affected by teachers' educational background, experiences, certificate credential, leadership expertise, persistence, preparedness course work, etc. (Darling-Hammond, 2000; Milanowski, 2004; Kane, Rockoff \& Staiger, 2008).

Throughout the last decade, the existing literature has shown that teachers have significant influences on students' academic enrichment, including lifelong success (Nye, Konstantopoulos \& Hedges, 2004; Chetty, Friedman \& Rockoff, 2014). According to a study based in Germany, students' outcomes are positively associated with the teacher content knowledge (Baumert et al., 2010). It was claimed that teacher quality is a fundamental element in student performance.

Like any other occupations in the world, including lawyers, doctors, architects, and accountants, teachers also have to understand and master their disciplines to be competent in their careers. However, it is insufficient for the teachers to only 
know and understand their subject matter (Labaree, 2000). The whole language teaching process requires teachers' deep understanding of the entire aspects of the curriculum (Richards, 2008). In this context, language teachers are required to equip themselves with various teaching pedagogical competencies, especially in promoting the willingness of students to use the Mandarin language (Jafri \& Manaf, 2020).

Comparatively, the existing literature on teachers' pedagogical practice reveals that there are very few qualitative explanatory studies on teaching Mandarin as FL specifically in Malaysia (Siti Martini and Ros Aizan, 2013; Lee \& Chow, 2015; Lew, 2020). Without defining the proper role of foreign language teachers who are responsible for arranging cognitive activities and students' development process, the development of a successful student's intellectual and creativity cannot take place. Thus, it is pertinent to develop a further understanding of teachers' pedagogical practices in teaching Mandarin as a foreign language, along with the perceptions that they have in ensuring the success of students' learning.

\section{Purpose of the Study and Research Questions}

The present study was aimed to describe the perceptions of language teachers in teaching Mandarin as a foreign language in MARA Educational Institutions. The exploration continues deeply in explaining the teachers' pedagogical practices in teaching Mandarin as a foreign language. In that regard, the mentioned research purposes have led to the formulation of the following research questions, which were:

1. What are the perceptions of MARA Educational Institutions teachers in teaching Mandarin as a foreign language?

2. What are the MARA Educational Institutions teachers' pedagogical practices in Mandarin language classroom instructions?

The findings of this study are practical. It includes the similarity of affective features and strategies used by a language teacher that affecting the learners' learning experiences and learning environments.

\section{Significance and Limitations of the Study}

This study significantly provides empirical evidence on how non-native Mandarin teachers teach the Chinese language to non-native learners. This includes the language teachers' perceptions and understanding of their choices of pedagogical practices. The results of this research may bring about further research on exploring the best practices that a language teacher can use during the processes of teaching and learning.

However, this research was constrained by certain limitations. This case study was limited to the data gained from the interview sessions only. The current study did not use any observation and document analysis to collect data. The semistructured interview was conducted with the Mandarin teachers who were willing to participate and share their insights into the study. The consistency of their responses was considered before making the conclusions. In addition to that, this study was restricted to the input of language teachers' pedagogical practices who teach Mandarin subjects in MARA Educational Institutions only. 


\section{Literature Review}

This study was designed to focus on MARA language teachers' perceptions and pedagogical practices through the lens of the 'actions' of Mandarin as a foreign language. To explore these propositions, it was essential to take into account different attributes of the nature of a language teacher, along with the aspects of Standards for Foreign Language Teaching and foreign language teaching approaches. The literature review ends with a look at relational approaches to conducting the research.

\section{The Nature of Language Teacher}

According to Cohen (1988), teaching is a practice of human improvement. In the context of educational change, there seems to be an increasing pattern of interest regarding the teachers' role in classroom settings, and their contribution to the desired success in preparing creative, critical, and humanistic students determined by the curricular guidelines (Borg, 2006; Madeira \& Lima, 2010). Williams and Burden (2007) indicated that:

"If the teacher-as-educator is one who is constantly re-evaluating in the light of new knowledge his or her beliefs about language, or about how language is learned, or about education as a whole, then it is crucial that teachers first understand and articulate their own theoretical perspectives" (p. 57)

Hence, it is compulsory for the teachers to have an in-depth understanding of the subject contents before projecting it through the instructional and pedagogical practices. Teacher content knowledge is categorized into three types, which are Subject Matter Knowledge, Pedagogical Content Knowledge, and Curricular Knowledge (Shulman, 1986). Shulman described Subject Matter Knowledge (SMK) as a teacher's understanding of their subject's structures, concepts, and facts. In contrast, Pedagogical Content Knowledge (PCK) illustrates the elements of subject matter knowledge, particularly the necessary features for teaching. Meanwhile, Curricular Knowledge (CK) delineates the needs for teacher's knowledge to sequence the curricular accordingly based on the concepts or topics, including determining the suitable resources or materials for a particular topic.

When the focus of education is to enhance students' learning, the quality of a teacher's pedagogical content knowledge plays a prominent role. Based on the explanation discussed above, PCK is chosen to answer the research questions. PCK is a mixture of both content and instructions to develop one's understanding regarding the particular problems, topics, or how to organize the issues, delineated, including a thorough arrangement to cater students' multiple levels of abilities and diverse interests (Shulman, 1987; Palanisamy \& Marzita, 2014).

Although Pedagogical Content Knowledge is not a teaching skill, it, however, influences teachers' teaching practices. Teaching ability must be nurtured to further develop students' competencies and dispositions, in a way that will train students to be resourceful, creative, and collaborative life-long problem solvers. 


\section{Communicative Language Teaching}

Foreign language research is a dynamic, ever-changing subject. Throughout the decades, studies on this field continue to evolve particularly in meeting the intended academic goals efficiently, as well as to help the learners to apprehend the language learned in a more comprehend manner (Richards \& Theodore, 2001; Jafri \& Manaf, 2020). The trends in exploring the language pedagogical started by facilitating the learners with cognitive-based approaches and the AudioLingual Approach (Larsen-Freeman, 2000). Grounded in behaviorist theories of linguistics, foreign language learning previously involved the activity of repetition and imitation of new knowledge (Skinner, 1957; Chomsky \& Skinner, 1959).

Nevertheless, in today's linguistic community, a more prominent study focuses on multilingualism among language learners, including the interplay of various linguistic systems in the language learner (Moeller \& Catalano, 2015). Among the approaches is Communicative Language Teaching (Hinkel, 2005). Instead of concentrating on the mastery of structures, several linguists and language teachers emphasized the demand for communicative proficiency among the language learners (Widdowson, 1978; Candlin, 1981; Richards \& Rodgers, 1986; Galloway, 1993). Hence, it is imperative for the teachers to provide the learners with the skills to decide when and where to use the language, or with whom to talk about, and by what means (Hymes, 1972; Richards \& Rodgers, 2001).

The concept of communication is divided into three main modes: interpersonal, interpretive, and presentational (American Council on the Teaching of Foreign Language's National Standards, 1999). Given a situation, a student engages in a conversation (interpersonal communication mode) and interpret the conversation (interpretive communication mode), before presenting his or her viewpoints (presentational communication mode). These three communication modes are in line with the Communicative Language Teaching framework. Through this framework, language is viewed as a means to sustain social interaction in everyday life (Hendrickson, 1991).

Under the umbrella of Communicative Language Teaching, there are four significant features of communicative competence, which are sociolinguistic competence, grammatical competence, discourse competence and strategic competence (Larsen-Freeman, 1986; Brown, 1994; Thompson, 1996; Savignon, 2002, 2006; Burke, 2010; Theisen, 2011). Such a notion embraces the great diversity of learners' skills, learning a language is more towards student-centered language teaching practices, as it focuses on task-oriented that will equip the students with extensive use of the language learned (Richards, 2006).

\section{Standards for Foreign Language Teaching}

Principally, language is regarded as foreign under two conditions which are the language is taught in a classroom and is not widely spoken in the society where the teaching takes place (Moeller \& Catalano, 2015). Foreign language teaching and learning have experienced a dramatic change. There is extensive research that has broadened the theoretical and scientific knowledge-base, particularly ways on 
how the students discover new information and apprehend the language learned (Richards, 1978; Ellis, 1994; ACTFL, 2006; De Angelis, 2007; NSFLEP, 2014).

Back in 1996, the American Council on the Teaching of Foreign Languages (ACTFL) first released a framework of Standards for Foreign Language Learning in the $21^{\text {st }}$ Century. This framework provides a set of goals for foreign language learning, which are communication, cultures, connections, comparisons, and communities (ACTFL, 2012; 2013). These five standards serve as a guideline for language educators to create and develop a language curriculum, as well as assessing language performance.

Likewise, language learners are also equipped with fundamental skills to achieve language proficiency. Learners are expected to communicate using the language learned, acknowledge the global issues including multicultural subjects, able to make connections across discipline, and comparing with the pre-established beliefs and new information and engaging in global communities. Consequently, foreign language learning allows learners to connect to a real-life situation. Hence, language learning should be emphasized on creating and developing meaningful communication (Lightbrown \& Spada, 2006).

\section{Research Methodology}

This case study aimed at exploring Mandarin teachers' perceptions and their pedagogical practices during teaching and learning processes. Hence, the current study was conducted qualitatively to obtain an in-depth understanding of the scenarios (Denzin \& Lincoln, 2003). The researchers also employed the case study design in understanding Mandarin teachers' perceptions and describing their pedagogical practices in specific circumstances (Stake, 1995; Yin, 2001).

This case study was carried out in Majlis Amanah Rakyat (MARA) Educational Institutions. Mandarin courses are being offered widely under MARA Educational Institutions, since 2013, from secondary education till higher education (Jafri \& Manaf, 2020). Currently, there are six MARA Professional Colleges and three MARA Junior Science Colleges (The Bitara Programme) which offer Mandarin courses. All the students under these colleges are compelled to take up Mandarin subjects throughout their studies.

At present, there are thirty-eight (38) Mandarin teachers working under these colleges. Through convenience purposive sampling, only six Mandarin teachers were selected as the informant of the current research. The data collection phase stopped at the sixth informant as the data had reached its saturation point. According to Introduction to Educational Research: A Critical Thinking Approach book (2012), Suter states that the saturation point is achieved when the data is exhaustive and there is little need for more sampling (pp. 350).

\section{Data Collection and Analysis Procedures}

The primary data for this case study were gained from multiple semi-structured interviews. The researchers used Patton's approaches (2001) as a guideline in designing the interview protocol. The formulation of the interview protocol was 
guided by the research purposes and questions. The interview protocol was submitted to the expert in ensuring the questions formulated is in line with the research purposes and research questions. The expert also reviewed the interview questions pertaining to its relevance, wording, and language. At this stage, the expert's review and evaluation also contributed to the validity of this research.

Altogether, there are thirty-eight Mandarin teachers under MARA Educational Institutions, and eleven teachers responded favorably with interest. From these eleven teachers, only six Mandarin teachers from five colleges were purposefully chosen upon their willingness and availability to participate. The researchers conducted individual semi-structured, audio-taped interviews at a time that was convenient for each teacher's schedule and each interview session lasted for 30 to 45 minutes. The interview sessions were conducted privately in the presence of the researchers and teachers. Member checking occurred during the interview session (Creswell \& Clark, 2007; Merriam, 2009; Creswell \& Poth, 2018).

A total of six interviews were transcribed for this study. Transcriptions resulted in 42 pages and 35,498 words that were coded, combined into codes, categorized, and thematized using Atlas. ti software version 8.1. Later, the analyzed data underwent a peer examination method in ensuring the credibility of the research, especially concerning the bias issue (Lincoln \& Guba, 1985; Creswell \& Poth, 2018).

\section{Establishing Trustworthiness}

Compared to quantitative research, qualitative research design enables the researchers to comprehend and grasp the phenomenon in specific context settings, in particular "real-world setting where the researcher does not attempt to manipulate the phenomenon of interest" (Patton, 2001). With this in view, the researchers are the instrument of this study. The validity and credibility of this case study depend on the capability and efforts of the researchers. Thus, it is very critical to establish the trustworthiness of the collected data. To validate the findings, the researchers engaged actively in peer examination, member checks, and providing rich and thick descriptions (Creswell \& Poth, 2018).

\section{Results and Discussion}

Based on the initial purposes, the current research intended to explore the perceptions of MARA teachers and their pedagogical practices in teaching Mandarin as a foreign language. Hence, the researchers identified the informant's criteria that will provide a comprehensive input into the study. Accordingly, based on the data gained from semi-structured interview sessions, the researchers constantly referred to the guiding research questions in the development of themes. In exploring teachers' perceptions in teaching Mandarin, there is one emergent theme which is the role of a language teacher. Meanwhile, under the exploration of teachers' pedagogical practices in teaching Mandarin as a foreign language, there are three themes developed, which are 1) "chalk and talk" style of teaching, 2) knowledge constructions and 3) the understanding of $21^{\text {st-century }}$ skills. 


\section{Role of Language Teacher}

Teacher perceptions and beliefs strongly influence teaching, as feelings and attitudes underlie behaviors (Smith \& Skarbek, 2013). During the in-depth interviews, all six research informants described their beliefs and roles in teaching Mandarin as a foreign language. The main role of a language teacher is to encourage and motivate the learners' love in learning Mandarin. As three informants explained:

RI 4: "It ends up you become a motivational speaker. Instead of teaching, you are more likely need to motivate the students to continue their studies".

RI 2: "Whenever students questioned why they need to learn Mandarin, I will explain why learning Mandarin is very important nowadays, and I will encourage them by sharing the experiences from graduated students who are currently working".

RI 3: "After for a while, I have no choice but to cultivate the students' interests from time to time".

Besides, one informant believed that "as a Mandarin teacher, one needs to be a passionate and high spirit to inspire the students to learn a foreign language" (RI 5). Another informant further explained that "creating an environment that loves to learn Mandarin is the ultimate role of a language teacher. Language teachers must converse in Mandarin between them, to encourage the students to apply their knowledge even outside of the classroom setting" (RI 3).

The findings above showed that most of the teachers agreed with the primary teaching role they held, especially in encouraging and motivating the students to learn the language, including creating a conducive environment for the learning. These responses were given due to their experiences in dealing with students' reactions in Mandarin classes.

RI 1: "The students did not feel the need to learn Mandarin language. They don't understand why they need to learn Mandarin".

RI 2: "The biggest issue in teaching Mandarin is when the students did not understand why they need to learn Mandarin".

RI 4: "Sometimes what makes me taken aback is that when the students have no interest in learning".

RI 6: "The number of students who are interested in learning Mandarin is not many, and many of them did not see the importance of learning Mandarin".

Instead of preparing and focusing to teach the language and its content, the teachers must first deal with the problem faced during the process of teaching and learning. They need to arouse learners' interest in learning Mandarin, as well as making the learners understand the reasons they must learn the Mandarin language. 


\section{The "Chalk and Talk" Style of Teaching}

The analyzed data showed that all the informants use the "chalk and talk" style of teaching, which is more towards teacher-centered. They believed that in knowledge transmission, teachers provide primarily frontal instruction to the students. Learning is teacher-structured as the teacher is the authority in the language class. Following are the responses given when asked what kind of instructional approaches that are often used during teaching and learning processes:

RI 3: "More towards teacher-centered. The most common style is "chalk and talk". 70\% of teaching hours will be the lecture-based class".

RI 1: "For the theoretical part, I still traditionally teach the students using a whiteboard - lecturing".

RI 2: "Usually, I will teach first. The weightage for teacher-centered to student-centered is 70/30".

RI 4: "It is a combination of both teacher-centered and student-centered. Here, the Mandarin class is 3 hours per week, so usually, the first two hours will be lecturing mood and the last one hour will more towards students' activities such as games".

RI 5: "Teacher-centred because this is a foreign language. In learning Mandarin, students need to listen to the teacher first".

RI 6: "The class will be in lecture mood because of the time constraint. One schooling year, we can only afford to finish up to five chapters. This is due to the school holidays and a lot of school activities throughout the year".

In conclusion, all the informants are comfortable using a teacher-centered method during the teaching and learning processes. There are two main reasons why they prefer teacher-centered teaching style, which is: time constraint, and theoretically, foreign language requires the students to listen and pay attention to the language teacher.

\section{Knowledge Constructions}

Another important theme that emerged during the interview sessions was knowledge constructions. Knowledge construction is a process that relates to the extent how the teachers facilitate the students in understanding, exploring, and determining the cultural assumptions, as well as framing the perspectives, references, and biases across disciplines that might affect the knowledge construction within it (Peter \& Armstrong, 1998; Banks, 2002). There are three primary practices highlighted in knowledge constructions. Firstly, the application of “听说读写” (Tīng shuō dú xiě), which is defined as listening-speaking-readingwriting.

RI 6: "Students must first listen a lot. Listen to what the teacher said. In learning Chinese, we have tìng - listening, shuō-speaking, dú-reading, 
and xiě - writing. Within these four skills, why listening skill must be mastered first? This is because we need to listen first before able to project what we heard. Like a small baby, they listen first to their surrounding before imitating what they heard. Same goes to the learning of new foreign language".

This type of teaching skills stress on the development of learners' listening, speaking, reading, and writing skills (Spencer, 2015; Jafri \& Manaf 2019). It is from the linguistic perspectives that describe the process of how speaking skills derive from listening, and simultaneously enhance the students' ability of reading, and later followed by writing skills (Poole, 2015; Jafri \& Manaf, 2019). Secondly, is the VAK Learning Styles (Flemming, 1995; 2006). This model emphasized three main learning styles, which are visual, auditory, and kinesthetic. It is claimed that most of the people have dominant or favorite styles of learning, while some others have a combination of two or three learning styles or an evenly balanced blend of these three learning styles.

RI 4: "One thing that I will make sure in my class, I will try to cater at least one teaching method to entertain each type of student. For instance, visual learners will be attracted to something they see, so I will make sure I will have prepared a PowerPoint slide or anything physical that they can see. While for the auditory learners, they learn the best by listening to what they hear, so I will give at least a short lecture or singing, and these types of students enjoy group discussions. Lastly is the kinesthetic learners. Sometimes at the end of the chapter, I will ask the students to make a role play or play something physical that they can move around".

Besides, that is the inculcation of Chinese culture during the teaching and learning process. The culture teaching in a foreign language classroom is an essential supplement as it enhances students' excitement in language learning (Jafri \& Manaf, 2019). One of the informants (RI 2) believed that "Mandarin is not just about learning the content only. I prefer the students to immerse themselves in the culture. For instance, when learning Chinese characters, I will prepare the Chinese calligraphy brush and let the students feel how the Chinese people write on paper, especially during the ancient dynasty".

In summary, language teachers must identify the right approaches with the right students at the right moment. Marzano (2007) stated that teaching is said to be effective when it dynamically combined the expertise of a vast range in pedagogical approaches with a deep understanding of students' individuality and needs during classes, at a particular point in time.

\section{The Understanding of $21^{\text {st }}$ Century Skills}

$21^{\text {st }}$-century skills have become inevitably significant in the $21^{\text {st }}$ century. $21^{\text {st }}$. century skills are a set of abilities and skills that needed to be developed within the students for them to succeed in life (Maria \& Kamisah, 2010; Yan, Jari \& Kirsi, 2018). However, through the data from interview sessions, it seemed that all five informants did not wholly understand the concept of $21^{\text {st-century skills. }}$

RI 1: "21st_century skills? All I know is technology. Am I right?". 
RI 2: "21st-century skills are about technology and the internet".

RI 3: "I am not a tech-savoy; till to the point that I'll be using 100\% technology in class".

RI 4: "21st-century skills is to integrate technology to improve the teaching and students' understanding".

RI 6: "21st_century skills? Hmm... That is the problem. If the teacher itself did not have a clear understanding of the $21^{\text {st }}$ century, then how to apply during the teaching and learning processes?".

Nonetheless, there is only one informant (RI 5) who understands the concept of

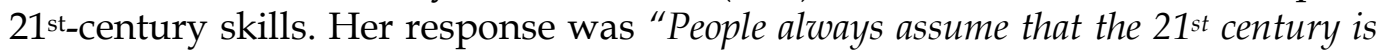
all about ICT and technology. But for me, it is not. If I am not mistaken, it is about 4C's right? The $21^{\text {st }}$ century is more towards student-centered. We act as a facilitator only and let the students direct their learning". She even added she learned about $21^{\text {st-century }}$ skills during her master's class.

From the findings discussed above, it can be concluded that the majority of the informants have less understanding of the concept of $21^{\text {st-century skills. They }}$

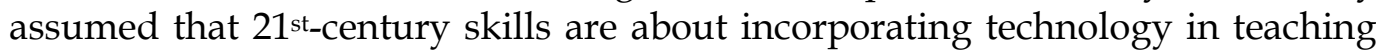
pedagogy. Clearly, this is something that needs to be worried about. As a teacher, one needs to have a clear understanding of particular concepts before being able to apply them during the teaching and learning processes.

\section{Language Teachers' Conflict of Interests}

According to Shmitt (2005) and Massey (2011), the researchers are required to apply vigorous synthesizing and data probing during the entire process of analysis, including the theme development from the unintended and emergent theme. Therefore, throughout the data analysis phase, there are two emerging themes identified, which are a) the need for professional development opportunities, and b) burnout symptoms.

\section{a) The Need for Professional Development Opportunities}

Research has proved that pre-established beliefs in teaching and learning restricted teacher's capability to generate and embrace new views, and subsequently their grammar-based-beliefs in education dominate their classroom settings (Horwitz, 1988; Freeman, 2002). This is also in line with the findings of the interview sessions. The data reported that the majority of the informants felt they were inadequately competent. The informants believed that they need to improve themselves, especially regarding teaching techniques and pedagogical practices.

RI 2: "Actually, I am not satisfied with myself. I think I need to improve my teaching technique. I am still figuring which pedagogy is the best and interesting for the students". 
RI 5: "I think there's a lot of things that I need to improve. A lot, especially in terms of my teaching pedagogy. I need to be more creative to attract students' interests".

RI 3: "I definitely need to improve my teaching. Teaching excellent students is not a big deal; the real deal is when dealing with less bright students".

RI 4: "For now, I don't think I am satisfied with my teaching. Because I think I can do better. I definitely need to attend more courses, especially regarding the 21st-century learning or any courses related to teaching foreign language".

The findings demonstrated that language teachers have varying principles about their teaching. Although the majority of them agreed that they need to improve themselves, the reasons behind that issue were varied depending on individual perspectives. In response to the findings, well-designed professional development courses or training may affect teachers' beliefs, and particularly concerning their in-class practices. It is also pertinent to consider teachers' backgrounds and diversify their curricula when designing a course or workshop.

\section{b) Burnout Symptom}

Burnout is commonly portrayed as a manifestation of emotional, physical, and interactional activities, specifically emotional exhaustion, depersonalization of clients, and a sense of lacking personal accomplishment (Maslach \& Jackson, 1981). The authors further explained that burnout consists of three features: 'emotional exhaustion', precisely explained as feelings of being emotionally overextended, 'reduced personal accomplishment', that is suffered by low spirits achievement teachers, meanwhile 'depersonalization' is illustrated as the progress of negative feelings and attitudes towards their careers. During the interview sessions, five informants stated that their job satisfaction has gone as they have reached the job burnout phase. The informants described their job burnout as follows:

RI 1: "Actually, I stop wondering. I just teach. I have lost interest in teaching Mandarin. To be honest, I did not see the good ending of this subject. I do not foresee how the students are going to use the knowledge for the future. Usually, when they have to finish Mandarin for a few semesters, it is done. Done. Done. And then it is all gone. And my interest in teaching also gone".

RI 2: "During the early involvement in this teaching field, I keep doing everything that I could for every class. I also continuously preparing all new things just to stimulate students. But then entering the third year, the fourth year, the fifth year, and currently, it is going down. Nowhere to be found. All I did is just prepare the students to score well in the examination".

RI 3: "In a wider context, I did not see the future of Mandarin. Because the students themselves did not foresee the future of Mandarin, when the 
students felt like that, it somehow affecting the teachers which made the teachers feel like... there's no need to do anything extra for the students.".

RI 4: "To be honest, I have been teaching for more than six years. I could not see where I am in the next 5 to 10 years except quitting this job. I feel like my teaching passion is no longer there. I am not what I used to be, not progressing, stagnant at the very same place. Sometimes you lose focus just because of the need to deal with other things such as the homeroom, doing series of intervention sessions with the problematic students, not including all the positions that you have like unit or clubs. I mean, our students are big enough, why we should treat them like they are still in high school like MRSM students".

RI 6: "This is my sixth year of teaching, and I already burn out. I used to teach diploma students. Although they are not cream students, I love the teaching environment there. Now I am teaching high school students, the chosen and bright students. My teaching satisfaction is no longer here because these students are busy focusing on their SPM examination. When I assigned them homework, they will say they have a lot of other homework, add maths, physics, etc. Since I entered MRSM, I nonstop counting days for retirement. Plus with a lot of work burden that is not related to teaching".

It can be concluded that the factor most described by the informants as influencing their job satisfaction and instruction planning was the work burden. It is crucially necessary to acknowledge the burnout symptoms among teachers, for the reason that burnout has substantial implications for teacher's motivation, mental health, job satisfaction, along with students' learning and behavior (Pyhalto et al., 2011).

\section{Conclusion}

Although this study involves only six key informants and the findings are, by all means, not generalizable, they, however, are beneficial to other teachers. Specifically, in the sense that every teacher is uniquely different individuals that have their teaching approaches; every teacher has different manifestations of their beliefs in teaching, and they engaged in change, as it is proposed to implement innovation towards the language curriculum. Theoretically, from the communicative approaches point of view, learner (student) is the key player in the foreign language process while teachers only act as a facilitator. Nonetheless, the students' necessities are challenging and demanding that teachers need to play a more active role that of the learners. This kind of scenarios that make teachers withstand stress over the language curriculum, and even worst to meet the expectation from stakeholders over the students' outcome from the Mandarin language classroom. After a thorough exploration and analyzing the data gained, the result of this study implies that there is a need for a more effective and sustainable teacher education and professional development program. These courses will inform the teachers about their beliefs and practices, which later enable them to develop new sets of beliefs and methods under educational reforms. 
Generally, it requires years of practice and classroom real-life experiences to make true expertise. However, it is astounding that the majority of the informants' reactions were contradictory and opposite the expectation, as most of them have been teaching for more than five years. Too often, the teachers were burdened with non-academic and clerical jobs which cause the focus and job satisfaction being ripped off from one's soul. Simultaneously, studies like the present one reveal the need for further classroom-based research. The findings provide insight for the teachers, administrators, teacher educators, and researchers, which later will help them to make decisions on how to improve Mandarin language instructions, language policy, educational training programs, and foreign language research at educational institutions.

\section{Recommendations for Future Research}

In reference to the outcomes and further discussions, the researchers found a glimpse into the implementation of Mandarin language learning; synthesizes existing research, as well as identifying possible areas for further exploration. The recommendations for future research are issues that might need to be tackled, especially, in enhancing teachers' pedagogical practices in teaching Mandarin.

\section{Exploring the Practices of Mandarin Teachers' Pedagogies from the Learners' Perspectives}

An analysis of Mandarin teachers' pedagogical practices from the eye of the students is an endeavor to reclaim voices in shaping and determining the quality of teachers' practices that learners thrive in. Input from the students' perspectives will enhance and improve teachers' pedagogical practices and quality of teaching, as well as ensuring that the pedagogical practices are relevant and prevalent to the current scenarios.

\section{The Inculcation of $21^{\text {st }}$ Century Pedagogy}

Many researchers have investigated the use of technology in teaching, however, there are few research which have explored other $21^{\text {st }}$ century skills in the language classroom environment (Young, 2003; Warwick \& Kershner, 2008; Ghavifekr \& Wan Athirah, 2015). Therefore, extensive research on the teachers' understanding of $21^{\text {st }}$-century skills and how they exercise their competencies throughout classroom instructions are very important. Consequently, for the interest of improving teacher education programs, qualitative studies are suggested to have a deeper and in-depth understanding of the domains that teachers typically hold or incremental beliefs, as well as determining how these beliefs affecting teachers' pedagogical thinking and practices.

\section{Grounding Theory for Language Teachers' Pedagogical Practices}

Approaches to accountability which involves a wider scope of active instructional practices and classroom pedagogical are pertinent in ensuring the success of student's learning. Teachers' pedagogical practices which are underpinned by the ideas and values that they have in the respective fields provide a valuable contribution role in enhancing the teachers' quality. Thus, language teachers need to understand their responsibilities, particularly on their active relationship between teaching and learning in producing lifelong learners. 


\section{References}

American Council on the Teaching of Foreign Languages (ACTFL). (2006). ACTFL Performance Guidelines for K-12 Learners. Yonkers, NY: American Council on the Teaching of Foreign Languages.

American Council on the Teaching of Foreign Languages (ACTFL). (2012). Alignment of the national standards of language learning with the common core state standards. Alexandria: American Council on the Teaching of Foreign Languages.

American Council on the Teaching of Foreign Languages (ACTFL). (2013). Program Standards for the Preparation of Foreign Language Teachers (Initial Level Undergraduate \& Graduate) For K-12 and Secondary Certification Programs. Council for Accreditation of Educator Preparation (CAEP). Retrieved from https://www.actfl.org/sites/default/files/CAEP/ACTFLProgramStandards20 13.pdf

Baker, J. A. (2006). Contributions of teacher-child relationship to positive school adjustment during elementary school. Journal of School Psychology, 44(3), 211-229. https:// doi.org/10.1016/j.jsp.2006.02.002

Banks, J. A. (2002). An introduction to multicultural education (6 $6^{\text {th }}$ edition). United States, US: Pearson Education.

Baumert, J., Kunter, M., Blum, W., Brunner, M., Voss, T., Jordan, A., et al. (2010). Teachers' mathematical knowledge, cognitive activation in the classroom, and student progress. American Educational Research Journal, 47(1), 133-180. https:// doi.org/10.3102/0002831209345157

Berg, B. L. (1998). Qualitative research methods for the social sciences (3rd edition). Boston, MA: Allyn and Bacon.

Borg, S. (2006). The distinctive characteristics of foreign language teachers. Language Teaching Research, 10(1), 3-31. https:/ / doi.org/10.1191/13621688061r182oa

Brown, H. (1994). Teaching by principles - An interactive approach to language pedagogy. New Jersey: Pretinence Hall.

Burke, B. M. (2010). Promoting communication in the target language with and among students. The Language Educator, 5(5), 50 - 53.

Celce-Murcia, M. (1991). Grammar pedagogy in second and foreign language teaching. TESOL Quarterly, 25, 459-480. https://doi.org/10.2307/3586980

Chetty, R., Friedman, J. N., \& Rockoff, J. E. (2014). Measuring the Impacts of Teachers II: Teacher Value-Added and Student Outcomes in Adulthood. American Economic Review, 104(9), 2633 - 2679. https://doi.org/10.3386/w19424

Chomsky, N., \& Skinner, B. F. (1959). Verbal behavior. Language, 35(1), 26-58. https://doi.org/10.2307/411334

Cilliers, E. J. (2017). The challenge of teaching Generation Z. PEOPLE: International Journal of Social Sciences, 3(1), 188-198. Retrieved from https://grdspublishing.org/index.php/people/article/view/322

Cohen, D. K. (1988). Teaching practice: Plus a change. In P. W. Jackson (Ed.), contributing to educational change: Perspectives on research and practice (pp. 27-84). Berkeley, CA: McCutchan.

Collins, J. (2009). Education techniques for lifelong learning: Lifelong learning in the $21^{\text {st }}$ century and beyond. Radiographics, 29, 613-622. https://doi.org/10.1148/rg.292085179

Creswell, J. W., \& Plano Clark, V. L. (2007). Designing and conducting mixed methods research. London: Sage Publications.

Creswell, J. W., \& Poth, C. (2018). Qualitative inquiry and research design: Choosing among five approaches (4th edition). Thousand Oaks, CA: Sage Publications Inc. 
Darling-Hammond, L. (2000). Teacher quality and student achievement. Education policy analysis archives, 8(1). https://doi.org/10.14507/epaa.v8n1.2000

De Angelis, G. (2007). Third or additional language acquisition. Multilingual Matters: University of California. https:// doi.org/10.21832/9781847690050

Denzin, N. K., \& Lincoln, Y. S. (2003). The landscape of qualitative research: Theories and issues ( $2^{\text {nd }}$ edition). London: Sage Publications.

Ellis, R. (1994). The study of second language acquisition. Oxford, UK: Oxford University Press.

Flemming, N. D. (1995). I'm different; not dumb. Modes of presentation (VARK) in the tertiary classroom, In A. Zelmer (Ed.) Research and Development in Higher Education. Proceedings of the 1995 Annual Conference of the Higher Education and Research Development Society of Australia (HERDSA), pp. 308-313.

Flemming, N. D. (2006). V.A.R.K Visual, Aural/Auditory, Read/Write, Kinesthetic. New Zealand: Bonwell Green Mountain Falls.

Freeman, D. (2002). The hidden side of the work: Teacher knowledge and learning to teach. Review Article, 35(1). https:// doi.org/10.1017/s0261444801001720

Fullan, M. (2001). The new meaning of educational change (3 ${ }^{\text {rd }}$ edition). New York, NY: Teachers College Press.

Fullan, M. (2003). Changes forces with a vengeance. London, UK: Routledge Falmer.

Ghavifekr, S., \& Wan Athirah, W. R. (2015). Teaching and learning with technology: Effectiveness of ICT integration in schools. International Journal of Research in Education and Science (IJRES), 1(2), 175-191. https:/ / doi.org/10.21890/ijres.23596

Hallinan, M. T. (2008). Teacher influences on students' attachment to school. Sociology of Education, 81 (3), 271-283. https://doi.org/10.1177/003804070808100303

Hendrickson, J. M. (1991). On Communicative Language Teaching, Hispania, 74(1), 197198. https://doi.org/10.2307/344583

Hinkel, E. (2005). Handbook of research in second language teaching and learning. Mahwah, NJ: Lawrence Erlbaum Associates.

Horwitz, E. (1988). The beliefs about language learning of beginning university foreign language students. The Modern Language Journal, 72(3). https://doi.org/10.1111/j.1540-4781.1988.tb04190.x

Hymes, D. J. (1972). Models of interaction of language and social life. In J. Gumperz \& D. Hymes (Eds.), Directions in sociolinguistics: The ethnography of communication (pp. 35-71). New York: Holt, Rinehart and Winston.

Jafri, N., \& Manaf, U. K. A. (2019). I am Hé: Creating Cultural Awareness in Teaching Mandarin as a Foreign Language. In R. M. Rasdi, M. K. Omar, A. B. Razali, L. Ismail, A. Abdullah, M. Yassin \& S. Othman (Eds.), $5^{\text {th }}$ International Conference on Educational Research and Practice (ICERP) 2019, Educating the Digital Society: Integrating Humanistic and Scientific Values (pp. 71-78). Selangor, Malaysia: The Faculty of Educational Studies, Universiti Putra Malaysia. Retrieved from http://spel3.upm.edu.my/max/dokumen/ICERP_ICERP_2019__PROCEEDINGS_(REVISED)_compressed.pdf

Jafri, N., \& Manaf, U. K. A. (2020). Looking into Students' Willingness to Communicate: A Case Study in Mandarin Language Learning. Universal Journal of Educational Research, 8(1A), 123-131. https://doi.org/10.13189/ujer.2020.081316

Kane, T. J., Rockoff, J. E., \& Staiger, D. O. (2008). What does certification tell us about teacher effectiveness? Evidence from New York City. Economics of Education Review, 27(6), 615-631. https://doi.org/10.3386/w12155 
Labaree, D. F. (2000). On the nature of teaching and teacher education: Difficult Practices that look easy. Journal of Teacher Education, 51(3), 228-233. https://doi.org/10.1177/0022487100051003011

Larsen-Freeman, D. (1986). Techniques and Principles in Language Teaching. New York: Oxford University Press.

Larsen-Freeman, D. (2000). Second Language Acquisition and Applied Linguistics. Annual Review of Applied Linguistics, 20, 165-181. https://doi.org/10.1017/s026719050020010x

Lee, P. L., \& Chow, T. V. F. (2015). Research on attitudes of learning Chinese as a foreign language learner in Malaysian University towards the Chinese language. The Science Education Article Collects, 12, 44-46.

Lew, Y. L. (2020). A case study on the application of cognitive strategies to Malay Mandarin learners. Jurnal Intelek, 15(1), -10.

Lightbown, P., \& Spada, N. (2006). How languages are learned (4th edition). Oxford, UK: Oxford University Press.

Lincoln. Y. S., \& Guba, E. G. (1985). Naturalistic Inquiry. Newbury Park, CA: SAGE Publications.

Madeira, M. Z., \& Lima, M. G. (2010). The significance of teaching practice in the constitution of teaching knowledge among nursing course professors at the Federal University of Piaui, Brazil. Texto \& Contexto - Enfermagem, 19(1), 70-77.

Maria, A., \& Kamisah, O. (2010). 21 $1^{\text {st }}$ century inventive thinking skills among primary students in Malaysia and Brunei. Procedia - Social and Behavioral Sciences, 9, 16461651. https://doi.org/10.1016/j.sbspro.2010.12.380

Marzano, R. J. (2003). What works in schools translating research into action. Alexandria, VA: Association for Supervision and Curriculum Development.

Marzano, R. J. (2007). The art and science of teaching: A comprehensive framework for effective instruction. Alexandria, VA: Association for Supervision and Curriculum Development.

Maslach, C., \& Jackson, S. E. (1981). The measurement of experienced burnout. Journal of Organizational Behavior, 2(2), 99-113. https://doi.org/10.1002/job.4030020205

Massey, O. T. (2011). A proposed model for the analysis and interpretation of focus groups in evaluation research. Evaluation and Program Planning, 34(1), 21-28. https:// doi.org/10.1016/j.evalprogplan.2010.06.003

Merriam, S. B. (2009). Qualitative Research: A Guide to Design and Implementation $3^{\text {rd }}$ edition). San Francisco: Jossey-Basess Publishers.

Milanowski, A. (2004). The relationship between teacher performance evaluation scores and student achievement: Evidence from Cincinnati. Peabody Journal of Education, 79(4), 33-53. https://doi.org/10.1207/s15327930pje7904_3

Moeller, A. J., \& Catalano, T. (2015). Foreign language teaching and learning. International Encyclopedia for Social and Behavioral Sciences $2^{\text {nd }}$ Edition, 9, 327-332. https:// doi.org/10.1016/b978-0-08-097086-8.92082-8

Morrow, K., \& Johnson, K. (1981). Communication in the Classroom: Applications and Methods for A Communicative Approach. London: Longman.

National Standards in Foreign Language Education Project. (1999). Standards for Foreign Language Learning in the $21^{\text {st }}$ Century (2 ${ }^{\text {nd }}$ edition). Lawrence, KS: Allen Press.

National Standards in Foreign Language Education Project .(2006). Standards for Foreign Language Learning in the $21^{\text {st }}$ Century ( $3^{\text {rd }}$ edition). Lawrence, KS: Allen Press.

National Standards in Foreign Language Education Project (NSFLEP). (2014). Alexandria, VA: World-Readiness Standards for Learning Languages. 
Nye, B., Konstantopoulos, S., \& Hedges, L. V. (2004). How large are teacher effects?. Educational Evaluation and Policy Analysis, 26(3), 237-257. https://doi.org/10.3102/01623737026003237

Palanisamy, K. \& Marzita, P. (2014). Effective teaching: Pedagogical Content Knowledge. Proceeding of International Joint Seminar Garut, Garut, Indonesia. Retrieved from https://www.researchgate.net/publication/303940850_Effective_Teaching_Ped agogical_Content_Knowledge

Patton, M. Q. (2001). Qualitative evaluation and research methods (3rd edition). Thousand Oaks, CA: SAGE.

Peters, J. M., \& Armstrong, J. L. (1998). Collaborative learning: People labouring together to construct knowledge. In I. M. Saltiel, A. Sgroi \& R. G. Brockett (Eds.), New directions for adult and continuing education, 79, 75-85. San Francisco, CA: JosseyBass.

Poole, F. J. (2015). Teaching Chinese as a Foreign Language: A Foreigner's Perspective. All Graduate Plan B and other Reports, 457(5), 1-161.

Pyhalto K., Pietarinen J., \& Salmela-Aro K. (2011). Teacher working - Environment Fit as A Framework For Burnout Experienced By Finnish Teachers. Teaching and Teacher Education, 27, 1101-1110.

Richards, J. C. (1978). Understanding Second and Foreign Language Learning: Issues and Approaches. Rowley, MA: Newbury House, pp. 71-93.

Richards, J. C. (2006). Communicative Language Teaching Today. Cambridge: Cambridge University Press.

Richards, J. C., \& Rodgers, T. S. (1986). Approaches and Methods in Language Teaching. Cambridge: Cambridge University Press.

Richards, J. C., \& Rodgers, T. S. (2001). Approaches and Methods in Language Teaching (2 ${ }^{\text {nd }}$ edition). Cambridge, New York: Cambridge University Press, pp. 153-177. https://doi.org/10.1017/cbo9780511667305.018

Rowling, J. K. (2002). Harry Potter and the Goblet of Fire. New York, NY: Scholastic.

Savignon, S. J. (2002). Interpreting Communicative Language Teaching. New Haven: Yale University Press.

Savignon, S. J. (2006). Communicative Language Teaching. Encyclopedia of Language $\mathcal{E}$ Linguistics (2 ${ }^{\text {nd }}$ edition), 2006, 673-679. https://doi.org/10.1016/B0-08-0448542/00610-6

Schmitt, R. (2005). Systematic metaphor analysis as a method of qualitative research. The Qualitative Report, 10(2), 358-394.

Shulman, L. S. (1986). Those who understand: Knowledge growth in teaching. Educational Researcher, 15(2), 4-14. https://doi.org/10.3102/0013189x015002004

Shulman, L. S. (1987). Knowledge and teaching: Foundations of the new reform. Harvard Educational Review, 57(1), 1-22. https:// doi.org/10.17763/haer.57.1.j463w79r56455411

Siti Martini, M., \& Ros Aizan, Y. (2013). Communicative Language Teaching (CLT) in Malaysian context: It's implementation in selected community colleges. Procedia Social and Behavioral Sciences, 90, 788-794. https://doi.org/10.1016/j.sbspro.2013.07.153

Skinner, B. F. (1957). Verbal Behavior. New York, NY: Appleton-Century-Crofts.

Smith, R. L., \& Skarbek, D. (2013). Professional teacher dispositions: Additions to the mainstream. Lanham, MD: Rowman \& Littlefield Education.

Spencer, W. A. (2015). Mandarin Chinese as a Second Language: A Review of Literature. Honors Research Projects, 210, 1-47.

Stakes, R. E. (1995). The art of case study research. Thousand Oaks, CA: SAGE. 
Suter, W. N. (2012). Introduction to Educational Research: A Critical Thinking Approach. Thousand Oaks, CA: SAGE.

Thompson, G. (1996). Some misconceptions about communicative language teaching. ELT Journal, 50(1), 9-15. https:// doi.org/10.1093/elt/50.1.9

Warwick, P., \& Kershner, R. (2008). Primary teachers' understanding of the interactive whiteboard as a tool for children collaborative learning and knowledge building. Learning, Media, and Technology, 33(4), 269-287. https://doi.org/10.1080/17439880802496935

Widdowson, H. (1978). Teaching language as communication. London: Oxford University Press.

Williams, M., \& Burdern, R. L. (2007). Psychology for Language Teacher. UK: Cambridge University Press.

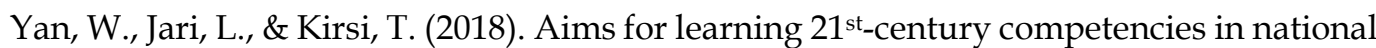
primary science curricula in China and Finland. Eurasia Journal of Mathematics, Science and Technology Education, 14(6), 2081-2095. https:// doi.org/10.29333/ ejmste/86363

Yin, R. K. (2011). Qualitative research from start to finish. New York, NY: The Guildford Press.

Young, S. C. (2003). Integrating ICT into second language education in a vocational high school. Journal of Computers Assisted Learning, 19, 447-461. https://doi.org/10.1046/j.0266-4909.2003.00049.x 